УДК 338.245 .4

\title{
ПОНЯТТЯ КОМПЛЕКСНОЇ ПОТУЖНОСТІ ДЕРЖАВИ ПРИ ОЦІНЦІ ВОЄННО-ЕКОНОМІЧНОЇ СКЛАДОВОЇ СЕКТОРУ БЕЗПЕКИ І ОБОРОНИ
}

\section{THE CONCEPT OF THE STATE COMPLEX POWER IN ASSESSING THE MILITARY-ECONOMIC COMPONENT OF THE SECURITY AND DEFENSE SECTOR}

\author{
Скляр Надія Михайлівна \\ кандидат економічних наук, доцент, \\ Національний інститут стратегічних досліджень; \\ Донецький державний університет внутрішніх справ \\ ORCID: https://orcid.org/0000-0001-9122-340X
}

\author{
Skliar Nadiia \\ National Institute for Strategic Studies; \\ Donetsk State University of Internal Affairs
}

\begin{abstract}
Стаття присвячена визначенню поняття комплексної потужності держави при оцінці воєнно-економічної складової сектору безпеки і оборони України. Досліджено теоретико-методичні засади визначення комплексної потужності держави та її структурних елементів. Надано компаративний аналіз компонентів потенціалу воєнної економіки. Запропонована архітектура дослідження структурних елементів комплексної потужності держави для можливості подальшого вибору методології дослідження воєнно-економічної складової сектору безпеки та оборони України.
\end{abstract}

Ключові слова: воєнна економіка, сектор безпеки та оборони, комплексна потужність держави, науковотехнічний потенціал, воєнно-економічний потенціал.

Статья посвящена определению понятия комплексной мощи государства при оценке военно-экономической составляющей сектора безопасности и обороны Украины. Исследованы теоретико-методические основы определения комплексной мощи государства и ее структурных элементов. Представлен компаративный анализ компонентов потенциала военной экономики. Предложена архитектура исследования структурных элементов комплексной мощи государства для возможности дальнейшего выбора методологии исследования военно-экономической составляющей сектора безопасности и обороны Украины.

Ключевые слова: военная экономика, сектор безопасности и обороны, комплексная мощь государства, научно-технический потенциал, военно-экономический потенциал.

The article is devoted to the definition of the concept of complex state power in assessing the military-economic component of the security and defense sector of Ukraine. Theoretical and methodological principles of determining the complex capacity of the state and its structural elements are studied. A comparative analysis of methods for assessing the potential of the military economy is given. The analysis of Ukrainian and foreign scientific publications revealed terminological differences in the definition of "complex State power". The key factor of the complex State power is the scientific and technical potential, which consists of (a) the state's ability to create advanced modern weapons and military equipment using the latest technologies, (b) the share of research and development in GDP, (c) the number of scientific and engineering personnel, (d) material technical base of scientific research, (e) the amount of state support through the financing of military-technical projects with public-private partnership enterprises. The study demonstrates the structural component of the complex capacity of the state, which consists of defense potential, scientific and technical, military, military-economic, social and moral, economic, political, and military-political potential. The article lists the state mechanisms for maintaining military power. The influential role of military-economic potential in the formation of complex State power is determined. The author's definition of military-economic potential is offered. The elements of potentials that make up the complex State power have been specified. When assessing the military-economic component of the security and defense sector, it is advisable to study the military-economic potential of the country and its impact on the overall complex State power. The archi- 
tecture of the study of the structural elements of the complex State power is proposed for the possibility of further choosing the methodology for the study of the security and defense sector of Ukraine and its military-economic component. Structural analysis of the components of complex state power will make it possible to identify risk-sensitive components of the military economy, optimize the algorithm of potential research and determine the further competitive strategy for the development of the security and defense sector.

Keywords: military economy, security and defense sector, complex state power, scientific and technical potential, military and economic potential.

Постановка проблеми. Основу військово-економічного сектору держави складає оборонно-промисловий комплекс (ОПК), як сукупність підприємств і організацій тієї чи іншої країни, які виготовляють озброєння і військову техніку для потреб збройних сил своєї держави та на експорт. Це «суспільний феномен, у підґрунті якого лежить збіг інтересів керівництва воєнних корпорацій, вищого командного складу ЗС і високих посадових осіб держави, а одним 3 головних проявів $\epsilon$ лобіювання бізнес-інтересів воєнної промисловості на вищому державному рівні та посилення її впливу на суспільні процеси. До ОПК звичайно зараховують ракетно-космічну, авіабудівну, суднобудівну, бронетанкову, радіоелектронну, артилерійсько-стрілецьку галузі» [1]. Усі ці галузі є елементами воєнно - економічної складової економічної безпеки України. Але в умовах глобалізації ризиків та асиметричності глобальних, міждержавних і регіональних конфрліктів, сучасних загроз економічній безпеці України, таких як макроекономічне розбалансування за головними показниками; згортання промислового виробництва; зниження інвестиційної активності, погіршення добробуту домогосподарств та зростання рівня безробіття; посилення боргового тиску, насамперед у державному секторі; підвищення тінізації економічної діяльності, критичної загрози відтоку науково-технічного людського капіталу та регулярного зовнішнього тиску від торгівельних, медіа- та кібервійн, військово-економічна складова держави потребує активної транссормації в напрямі стимулювання випереджального розвитку зі структурно-технологічною модернізацією державних інституцій, посиленням рівня конкурентоспроможності на міжнародних ринках 3 використанням новітніх (притаманним постіндустріальним країнам) підходів та технологій, та залученням науково обгрунтованої конкурентної економічної моделі розвитку, направленої на комплексну потужність держави [2, с. 92-93].

Аналіз останніх досліджень і публікацій. Термінологічний та методологічний апарат оцінки військової потужності держав за останні роки досліджували ціла низка національних та закордонний фрахівців 3 воєнної безпеки та міжнародні організації, які пов'язані з системами безпеки і оборони, такі як SIPRI, Stratfor, RAND, CIA, інформаційноаналітичний центр BICC, Bloomberg, Міжнародний центр конверсії в Бонні (ФРН). Частіше всього військові фрахівці використовують об'єктивні кількісні показники, математичний та статистичний апарат дослідження та експертне оцінювання. В доробках закордонних фрахівців, таких як Кл. Кнорра, Г. Кліфорда, Р. Клайна, П. Сорокіна, Н. Спайкмена, Д. Стінгера, В. Фуке розроблялися системи показників, які б могли оптимально характеризувати різні сторони оборонних можливостей країн. Українськими науковцями І. Біньком, В. Згурецем, М. Гончаром, М. Кулінічем, В. Мунтіяном, В. Смолянюком, І. Ткачем, М. Ткачем, В. Шлемком розглянута взаємозалежність військової могутності України та рівня ії воєнної та національної безпеки.

Виділення невирішених раніше частин загальної проблеми. Дослідження вітчизняних та закордонних науковців хоча й дозволяє окреслити коло актуальних військово-економічних проблем, але не надає повної характеристика поняття «комплексної потужності держави» при оцінці воєнно-економічної складової сектору безпеки та оборони з урахуванням сучасних військово-економічних реформ України та збройного конфрлікту, в якому країна перебуває з 2014 р.

Формулювання цілей статті (постановка завдання). Ціллю дослідження $є$ проведення аналізу компонентів комплексної потужності держави 3 метою визначення подальшої методології оцінки воєнно-економічної складової сектора безпеки та оборони.

Виклад основного матеріалу дослідження. Військова потужність держави - це сукупність матеріальних і духовних сил країни і здатність мобілізувати їх для досягнення цілей війни. Вона складається з економічних, соціальних, науково-технічних, політичних i власне військових потенціалів (фракторів). Як зазначає Смоленюк В.Ф., військова могутність держави з позиції системологічної кон- 
цепції відноситься до комплексного показника досконалості національної оборонної сфери [3]. Українські дослідники військової науки Семененко О.М. [4] та Мунтіян В.І. [5] оборонну потужність визначають як сукупність людських, матеріальних, військових, політичних та інших об'єктивно існуючих можливостей держави, а також як здатність мобілізувати і використовувати ці можливості для забезпечення обороноздатності країни, досягнення кінцевих цілей війни [4-5]. В наукових доробках зарубіжних авторів одне 3 перших аналогічних понять щодо військової потужності держави - «національну потужність» було введено Кл. Кнорром - профресором Пристонського університету США. Він фрормулює національну потужність як поняття, яке включало в себе економічні можливості, ефрективність роботи адміністрації та схильність держави до воєнної мобілізації [6, с. 101-104].

Напрацювання Михайлова В.С. та Єфрімової B.В. висвітлюють базові методологічні та методичні підходи відносно побудови та розрахунків індексів (рейтингових оцінок) для можливої оцінки військової потужності країн світу та здійснення коректного компаративного аналізу української військової потужності з системою зазначених показників інших країн [7, с. 381-392].

На значні невизначеності в методологічних аспектах трактування та оцінювання оборонного потенціалу та воєнно-економічного потенціалу, як складових комплексної потужності держави зауважують військові фрахівці Семененко О., Салкуцан С., Романченко О., Марко Є., Добровольська Л., Ремез А. [8, с. 161-177], М. Ткач та І. Ткач [9, с. 106-118].

Як визначається 3 напрацювань українських та зарубіжних фрахівців з військової економіки, поняття «оборонна потужність», «військова потужність», «національна потужність» не $€$ тотожними. Військова потужність входить до складу оборонної потужності та фрормує національну потужність держави. Для оцінки воєнно-економічної складової сектору безпеки і оборони України доречніше використовувати поняття «комплексна потужність держави», враховуючи необхідність використання великої кількості показників, які характеризують усю складність та багатоаспектність структури даного френомену. Зазначимо, що до сих пір не існує ні чіткої методології, ні теоретичної бази для точної оцінки сукупності ресурсів, які можуть бути використані у військових цілях, та оптимального визначення розмірів воєнного потенціалу в цілому, як складової комплексної потужності держави.
Отже, комплексна потужність держави це багатокомпонентне поняття, структурними елементами якого $€$ оборонний потенціал 3 науково-технічною, воєнною, воєнно-економічною, соціальною та моральною, економічною, політичною та воєнно-політичною складовими.

Забезпечення комплексної потужності держави здійснюється завдяки складної системи спеціалізованих структур національного господарства, цілеспрямовано використовуваних для економічного базису військового будівництва, підготовки та захисту від воєнного нападу, надійного захисту національної безпеки. Функціональне призначення комплексної потужності держави полягає в тому числі і у виробництві величезного асортименту продукції військового призначення (озброєння і військова техніка), а також в матеріально-технічному забезпеченні військової організації держави.

До державних механізмів підтримання військової потужності держави українські науковці відносять: державно-політичний механізм фрормування військової потужності держави; юридично-правовий механізм ії забезпечення; механізм структурно-фрункціональної оптимізації Збройних Сил України як провідного суб'єкту забезпечення комплексної потужності держави; кадровий механізм їі забезпечення; фрінансово-економічний механізм їі формування; механізм цивільного контролю над процесами формування та використання комплексної військової потужності; механізм державно-патріотичного забезпечення. В умовах сьогодення в Україні визначається нерівномірність характеру впливу зазначених механізмів на якість комплексної військової потужності, який переважно визначається В недосконалості фрінансово-економічного забезпечення військової сфрери, необхідності подальшого доопрацювання кадрового, юридично-правового механізму згідно зі стандартами НАТО, механізму цивільного контролю над її наявним станом [3].

Забезпечення воєнно-економічної складової сектору безпеки та оборони України представляє собою складну сукупність різноманітних за характером та численних по фрормі виробничих, управлінських, організаційних, логістичних, контролюючих та інших заходів, які націлені на задоволення потреб збройних сил та забезпечення безпеки держави. Оборонна промисловість, яка виробляє озброєння, військову техніку, продукцію військового призначення та подвійного використання фрормує фрундамент воєнно-економічної складової сектору безпеки 
та оборони країни, є складовою оборонно-промислового комплексу та відноситься до ключової компоненти комплексної потужності держави. Оборонно-промисловий комплекс (ОПК) об'єднує організації, що випускають продукцію військового призначення та надають спеціальні послуги для збройних сил як своєї країни, так і інших держав. У цьому напрямку важливим аспектом збільшення комплексної потужності держави $€$ військово-технічне співробітництво та зовнішньоторговельні зв'язки підприємств ОПК та підприємств державно-приватного партнерства, оскільки експортні поставки військової техніки фрормують прибутки країни, а військовий імпорт сприяє завчасному створенню значних запасів озброєння та військової техніки (ОВТ), стратегічних матеріально-технічних запасів, які необхідні Збройним силам країни в умовах воєнного протистояння. Кінцевою метою ОПК $є$ гарантування забезпечення оснащення ЗСУ та силових структур новими зразками, типами та видами озброєння, військової та спеціальної техніки в необхідній кількості та в визначені терміни.

Для визначення воєнно-економічного потенціалу, як складової комплексної потужності держави, першочерговим завданням $€$ дослідження масштабів, рівня розвитку і структури матеріального виробництва. Українські науковці Ткач І. та Ткач М. визначають «воєнно-економічний потенціал як сукупність двох потенціалів економічного та воєнного, адже під час війни вся економічна потужність держави буде націлена на забезпечення потреб оборони тобто воєнний потенціал буде нарощуватися за рахунок економічного» [9, с. 109]. Як зауважує група військових дослідників на чолі з Семененко О., низка фрахівців відмовляються від поняття воєнноекономічний потенціал та використовують поняття економічний потенціал, виходячи 3 того, що для економічного забезпечення підготовки і ведення війни повинні використовуватися всі економічні можливості країни [8, с. 164]. На нашу думку, доречніше застосування терміну воєнно-економічного потенціалу, оскільки до нього відносяться матеріальні засоби, що виділяються державою на потреби ЗСУ як у мирний час, так і у воєнний, а економічний потенціал країни у політекономічному розрізі - це система відносин економічної власності між людьми у взаємодії 3 розвитком продуктивних сил та базисними елементами господарського механізму, що виступають основним джерелом розвитку економічної системи, її можливостей.
Ключовим чинником комплексної потужності держави в умовах сучасного технонаціоналізму, який забезпечує сталий розвиток та конкурентоспроможність держави у світі є науково-технічний потенціал. Він тісно пов'язаний зі Збройними силами, які є головним споживачем передових наукових, технологічних та технічних досягнень та, одночасно 3 ОПК, потужним, активно діючим каталізатором розвитку фундаментальної та прикладної науки і економіки в цілому. При оцінці науково-технічного потенціалу враховують можливість держави до створення досконалих сучасних ОВТ із застосуванням новітніх технологій, частку витрат НДКР у ВВП, чисельність наукових та інженерно-технічних кадрів, статистика яких тяжіє до збільшення відсотка міграції наукових кадрів за кордон та скорочення наукових та науково-дослідних інститутів, матеріальнотехнічна база наукових досліджень, кількість державної підтримки за рахунок фрінансування воєнно-технічних проектів 3 підприємствами державно-приватного партнерства. Усі вищезазначені компоненти фрормують архітектуру науково-технічного потенціалу, який безпосередньо пов'язаний 3 воєнно-економічним потенціалом та такими компонентами соціального потенціалу, як стан та доступність освіти; рівень забезпечення інформаційнокомунікативних технологій в державі (рис. 1).

Складовими воєнного потенціалу за думкою багатьох науковців з воєнної економіки $€$ : чисельність збройних сил, рівень забезпеченості їх озброєнням та військової технікою, стан та рівень розвитку військової інфрраструктури, рівень бойових навичок особового складу, рівень оперативно-тактичної підготовки командних кадрів, рівень матеріально-технічного забезпечення військ, рівень розвитку системи управління військом. Співвідношення військових витрат до чисельності збройних сил зазначає вплив наступних складових воєнного потенціалу на комплексну потужність держави: рівень забезпеченості збройних сил озброєнням та військовою технікою; рівень бойової підготовки військ; рівень матеріально-технічного забезпечення особового складу та стан та рівень розвитку військової інсрраструктури [10, с. 86].

До складу комплексної потужності держави відносяться ще такі компоненти, як соціальний та моральний потенціал, політичний потенціал та воєнно-політичний потенціал, характеристики якого $€$ пов'язуючими елементами між рівнем соціально-політичної єдності громадянського суспільства та державної 


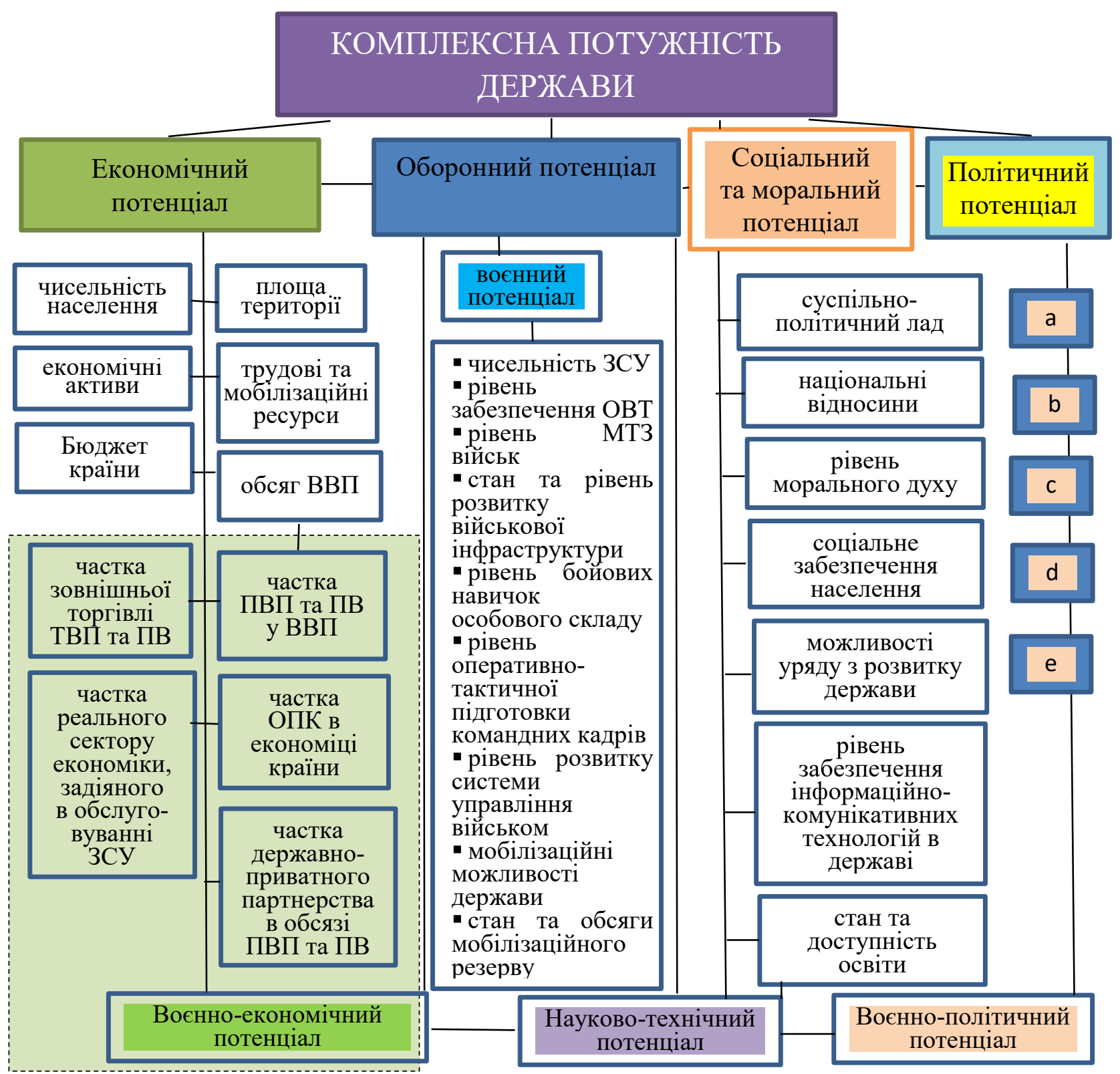

Умовні скорочення: ВВП - внутрішній валовий продукт; ОПК - оборонно-промисловий комплекс; ЗСУ - збройні сили України; ПВП та ПВ - продукція воєнного призначення та подвійного використання; ТВП та ПВ - товари воєнного призначення та подвійного використання; ОВТ - озброєння та військова техніка; МТЗ - матеріально-технічне забезпечення.

\section{Рис. 1. Логіко-структурна схема зв'язку показників складових комплексної потужності держави} Джерело: складено автором за [4; 5; 8; 9]

влади, які залежать від ідеологічних, духовноморальних та соціально-економічних засад держави.

Компонентами політичного потенціалу є: (a) визнання держави світовим співтовариством; (b) рівень забезпечення конституційних прав і свобод громадян; (c) рівень благоустрою громадян; (d) рівень захищеності громадян від зовнішніх та внутрішніх загроз; (е) рівень соціально-політичної єдності громадянського суспільства (рис. 1).
Конструктивний аналіз складових комплексної потужності держави зазначений на рис. 1.

Таким чином, структурну складову комплексної потужності держави становлять економічний, оборонний, соціальний та моральний, політичний потенціали. До складу оборонного потенціалу входять показники воєнного, науково-технічного, соціального та морального потенціалу, воєнно-політичного потенціалу, пов'язуючою складовою якого є воєнно-економічний потенціал. 
Висновки. Комплекснапотужність державице багатокомпонентне поняття, структурними елементами якого $€$ оборонний потенціал 3 науково-технічною, воєнною, воєнно-економічною, соціальною та моральною, економічною, політичною та воєнно-політичною складовими, яка забезпечується системою спеціалізованих структур національного господарства, цілеспрямовано використовуваних для економічного базису військового будівництва, підготовки та захисту від воєнного нападу, надійного захисту національної безпеки завдяки державно-політичного, юридично-правового, кадрового, фрінансово-економічного, державно-патріотичного механізмів державного підтримання, механізмів структурно-срункціональної оптимізації Збройних Сил України та цивільного контролю над процесами фрормування та її використання.
Воєнно-економічний потенціал $€$ компонентою комплексної потужності держави, складовою оборонного та економічного потенціалів, який характеризує можливості держави в забезпеченні максимуму матеріальних засобів на військове споживання для задоволення потреб збройних сил у мирний час та здатність економіки забезпечити потреби країни у випадку протистояння збройній агресії. При оцінці воєнно-економічної складової сектору безпеки та оборони доцільно досліджувати воєнно-економічний потенціал країни та його вплив на комплексну потужність держави. Структуровий аналіз складових комплексної потужності держави надасть можливість у визначенні методології дослідження сектору безпеки і оборони, виявленні ризик-чутливих компонентів з подальшою розробкою конкурентної секторальної стратегії розвитку.

\section{СПИСОК ВИКОРИСТАНИХ ДЖЕРЕЛ:}

1. Вікіпедія. Воєнно-промисловий комплекс. URL: https://uk.wikipedia.org/wiki/Воєнно-промисловий комплекс

2. Скляр Н. Сутність поняття «військово-економічного сектору» в системі національної безпеки України. Матеріали V міжнародної науково-практичної конфреренції «Управління інноваційним розвитком на макро-, мезо- та мікрорівняХ». 06-07 червня 2019 р. ОНПУ. м. Одеса. С. 92-95. URL: https://economics.opu.ua/files/ science/innov_roz/2019/92.pdf

3. Смолянюк В.Ф. Військова могутність України: теоретико-методологічні засади фрормування і розвитку (політологічний аналіз досвіду 1990-х років). Ірпінь : Перун, 2000. 448 с.

4. Семененко О.М. Методологічні основи воєнно-економічного супроводження програм розвитку Збройних Сил України : дис. ... докт. військ. наук : 20.01.05. Київ : ЦНДІ ЗС України, 2018. 640 с.

5. Мунтіян В.І. Економіка та оборонні витрати: аналіз зарубіжних досліджень і український шлях розвитку. Київ : Наук.-дослід. фін. ін-т при М-ві фрінансів України, 1998. 463 с.

6. Балахонцев Н. Зарубежные методы оценки потенциала стран. Зарубежное военное обозрение. 2010. № 11. С. 101-114.

7. Михайлов В.С., Єфрімова В.В. Рейтингові оцінки у військовій ссрері: методологія і практика. Університетські наукові записки. 2018. № 67-68. C. 381-392. URL: https://journals.indexcopernicus.com/api/file/ viewByFileld/589963.pdf

8. Семененко О., Салкуцан С., Романченко О., Марко Є., Добровольська Л., Ремез А. Основні методологічні аспекти оцінювання взаємозв'язку оборонного та економічного потенціалу держави у рамках формування вимог до її ефективного розвитку. Scientific Papers "Social Development and Security". 2020. Vol. 10. No. 6. P. 161-177. DOI: $10.33445 /$ sds.2020.10.6.15

9. Ткач М., Ткач І. Аналіз воєнно-економічних потенціалів деяких країн світу. Journal of Scientific Papers "Social development and Security". 2019. № 9(3). P. 106-118. DOI: http://doi.org/10.33445/sds.2019.9.3.8

10.Буравлев А.И. К вопросу об оценке военно-экономического потенциала государства. Вооружение и экономика. 2017. № 3(40). С. 78-97.

\section{REFERENCES:}

1. Vikipediia. Voienno-promyslovyi kompleks [Wikipedia. Military-industrial complex]. Available at: https://uk.wikipedia.org/wiki/Воєнно-промисловий комплекс (accessed 28 December 2020).

2. Skliar, N. (2019). Sutnist poniattia "viiskovo-ekonomichnoho sektoru" v systemi natsionalnoi bezpeky Ukrainy [The essence of the concept "military-economic sector" in the system of national security of Ukraine]. Materialy $\checkmark$ mizhnarodnoi naukovo-praktychnoi konferentsii "Upravlinnia innovatsiinym rozvytkom na makro-, mezo- ta mikrorivniakh" - V International Scientific and Practical Conference "Management of innovative development at the macro-, meso- and micro-levels" (Odessa, June 06-07, 2019), pp. 92-95. Odessa: Odessa National Polytechnic University. Available at: https://economics.opu.ua/files/science/innov_roz/2019/92.pdf (in Ukrainian) 
3. Smolianiuk, V.F. (2000). Viiskova mohutnist Ukrainy: teoretyko-metodolohichni zasady formuvannia i rozvytku (politolohichnyi analiz dosvidu 1990-kh rokiv) [The military power of Ukraine: theoretical and methodological principles of formation and development (political analysis of the experience, 1990)]. Irpin: Perun. (in Ukrainian)

4. Semenenko, O. (2018). Metodolohichni osnovy voienno-ekonomichnoho suprovodzhennia prohram rozvytku Zbroinykh Syl Ukrainy [Methodological bases of military-economic support of development programs of the Armed Forces of Ukraine]. Dr. thesis. Kyiv: Central Research Institute of the Armed Forces of Ukraine. (in Ukrainian)

5. Muntiyan, V. (1998). Ekonomika ta oboronni vytraty: analiz zarubizhnykh doslidzhen i ukrainskyi shliakh rozvytku [Economics and defense spending: analysis of foreign research and the Ukrainian way of development]. Kyiv: Nauk.-doslid. Finn. Inst. at the Ministry of Finance of Ukraine. (in Ukrainian)

6. Balahontsev, N. (2010). Zarubezhnyie metodyi otsenki potentsiala stran [Foreign methods for assessing the potential of countries]. Zarubezhnoe voennoe obozrenie - Foreign military review, 11, 101-114. (in Russian)

7. Mykhaylov, V.S., \& Efimova V.V. (2018). Reitynhovi otsinky u viiskovii sferi: metodolohiia i praktyka [Ranking Estimates in the Military Sphere: Methodology and Practice]. Universytetski naukovi zapysky - University scientific notes, 67-68, 381-392. Available at: https://journals.indexcopernicus.com/api/file/ viewByFileld/589963.pdf (in Ukrainian)

8. Semenenko, O., Salkutsan S., Romanchenko O., Marko Y., Dobrovolska L., \& Remez A. (2020). Osnovni metodolohichni aspekty otsiniuvannia vzaiemozviazku oboronnoho ta ekonomichnoho potentsialu derzhavy u ramkakh formuvannia vymoh do yii efektyvnoho rozvytku [Main methodological aspects of assessing the relationship between the defense and economic potential of the state in the framework of forming requirements for its requirements]. Scientific Papers "Social Development and Security", 10(6), 161-177. DOI: 10.33445/sds.2020.10.6.15 (in Ukrainian)

9. Tkach, M., \& Tkach, I. (2019). Analiz voyenno-ekonomichnykh potentsialiv deyakuh stran myra [Analysis of the military-economic potential of some countries of the world]. Social development \& Security, 9(3), 106-118. DOI: http://doi.org/10.33445/sds.2019.9.3.8 (in Ukrainian)

10. Buravlev, A.I. (2017). K voprosu ob otsenke voenno-ekonomicheskogo potentsiala gosudarstva [On the question of assessing the military and economic potential of the State]. Vooruzhenie i ekonomika - Armament and economy, 3(40), 78-97. (in Russian) 